Jurnal PRIMATIKA, Volume 8, Nomor 1, Juni 2019

\title{
PENALARAN SPASIAL SISWA PADA TAHAPAN OPERASIONAL FORMAL MENURUT PIAGET DALAM MEMECAHKAN MASALAH GEOMETRI
}

\author{
Kurniawan \\ Dosen Pendidikan Matematika FKIP Universitas Mulawarman \\ Email: kurniawan@fkip.unmul.ac.id
}

\begin{abstract}
ABSTRAK
Penelitian ini bertujuan untuk mengeksplorasi penalaran spasial dari 61 siswa laki-laki dan 63 jenis kelamin perempuan berusia 12-14 tahun. Penelitian ini menggunakan metode deskriptif dengan dua analisis data yaitu kuantitatif dan kualitatif. Instrumen menggunakan tes pemecahan masalah geometri (TPMG). Tes ini terdiri dari tiga pertanyaan berdasarkan visualisasi spasial, rotasi mental, dan orientasi spasial. Setelah siswa bekerja di TPMG, 45 siswa jender laki-laki dan 47 siswa jender perempuan menjawab dengan benar masalah nomor 1, 41 siswa jender laki-laki dan 46 siswa jender perempuan yang menjawab dengan benar pertanyaan nomor 2, dan 37 siswa jender laki-laki dan 36 siswa jender perempuan yang menjawab benar masalah tidak. 3. Dalam menyelesaikan TPMG, ada perbedaan antara siswa dan jenis kelamin laki-laki dan perempuan, untuk jenis kelamin laki-laki dapat memecahkan masalah dengan hanya menggambar jaring kubus di dimensi 2 sementara perempuan gender membuat jaring dari kertas keras untuk menyelesaikan TPMG.
\end{abstract}

Kata kunci: Penalaran Spasial, Gender, Pemecahan Masalah.

\begin{abstract}
The research aims to explore the spatial reasoning of 61 male gender students and 63 female gender aged 12-14 years. This research used descriptive method with two data analyzes namely quantitative and qualitative. Instrument uses geometry problem solving test (TPMG). The test consisted of three questions based on spatial visualization, mental rotation, and spatial orientation. After the students worked on TPMG, 45 male gender students and 47 female gender students answered correctly problem number 1, 41 male gender students and 46 female gender students who answered correctly question number 2 , and 37 male gender students and 36 female gender students who answered correctly problem no. 3. In solving of TPMG, there were differences between students and genders of men and women, for male gender it could solve problems by simply drawing cube nets in dimension 2 while gender women made nets from hard paper to solve TPMG.
\end{abstract}

Keywords: Spatial Reasoning, Gender, Problem Solving. 


\section{PENDAHULUAN}

Terdapat lima standar proses pendidikan matematika, yaitu (1) pemecahan masalah, (2) penalaran, dan bukti, (3) komunikasi, (4) koneksi, dan (5) representasi (NCTM dalam Subarinah, 2013). Stacey (2010) menyatakan "reasoning in mathematics is a cognitive process of looking for reasons and looking for conclusions", penalaran matematika adalah proses kognitif dalam mencari alasan dan mencari kesimpulan. Kemampuan kognitif siswa yang terkait dengan kemampuan matematika antara lain adalah penalaran spasial dan penalaran kuantitatif.

Penalaran spasial adalah salah satu tingkat proses berpikir untuk menvisualisasikan objek dan memahami secara abstrak objek atau simbol (Risalah, at al, 2016). National Research Council (dalam Risalah, at al, 2016) menyatakan bahwa berpikir atau penalaran spasial, melibatkan lokasi dan pergerakan objek dan diri sendiri, baik secara mental maupun fisik. Hal ini bukan kemampuan atau proses tunggal tetapi mengacu pada sejumlah konsep, alat dan proses. Kajian tentang penalaran spasial adalah substansi penting untuk kemampuan penalaran spasial dalam geometri, pengukuran, dan pemecahan masalah baik dalam tingkat awal hingga sekolah tinggi dan seterusnya.

Berdasarkan perkembangan kognitif menurut Piaget siswa mulai dari bayi hingga dewasa terbagi menjadi 4 tahapan yaitu (1) sensor motor 0-2 tahun; (2) praoperasional 2-7 tahun; (3) operasional kongkret 7-11 tahun; (4) operasional for- mal 11 tahun dan seterusnya. (Simatwa, 2010).

Pada tahapan operasional formal siswa sudah tidak menggunakan benda/objek konkret untuk membantu berpikir. Siswa yang telah mencapai tahap operasi formal, dapat membangun teori dan membuat kesimpulan logis tentang konsekuensinya tanpa memiliki pengalaman langsung sebelumnya pada subjek. Dia dapat menangani abstraksi dan secara mental mengeksplorasi persamaan dan perbedaan karena dia telah menguasai reversibilitas dan desentralisasi (Simatwa, 2010).

Dalam hasil TIMSS 2011 assessment framework untuk capaian rata-rata peserta Indonesia adalah 386 yang berarti berada pada level rendah (Mullis, at al, 2012). Untuk persentase menjawab benar untuk soal domain konitif reasoning (penalaran) sebesar 17\% dengan rata-rata internasional sebesar $30 \%$. Ini berarti bahwa kemampuan siswa dalam menjawab dengan benar soal untuk domain kognitif untuk reasoning (penalaran) masih rendah. Untuk dimensi konten bilangan dan geometri dan pengukuran, persentase menjawab benar untuk kedua konten sebesar 24 dengan rata-rata internasional sebesar 43 untuk konten bilangan dan 39 untuk konten geometri dan pengukuran (Mullis, at al, 2012).

\section{METODE PENELITIAN}

Penelitian ini merupakan jenis penelitian kualitatif dengan metode studi kasus. Penggunaan jenis kualitatif didasarkan atas pertimbangan karena penelitian ini berlatar alami dan instrumen utama dalam penelitian ini adalah peneliti sendiri. Analisis 
dilakukan secara mendalam pada siswa gender laki-laki dan perempuan dalam memecahkan masalah matematika geometri.

Subjek dalam penelitian ini adalah siswa yang terdiri dari 4 kelas, yaitu kelas VIII kemudian dipilih 2 subjek yang masing-masing dengan 1 orang gender lakilaki dan 1 orang perempuan. Untuk menentukan subjek peneltitian, dilakukan langkah-langkah sebagai berikut:

1) Menetapkan kelas untuk memilih subjek pada setiap sekolah yaitu kelas yang memiliki kemampuan matematika tinggi. Untuk mengetahui kemampuan matematika pada tiap kelas dilakukan konsultasi dengan guru matematika yang mengajar di kelas tersebut.

2) Memberikan masalah geometri kepada setiap kelas yang telah ditentukan.

3) Mengoreksi hasil pekerjaan siswa pada masalah geometri yang diberikan.

4) Berdasarkan hasil pekerjaan menjawab benar dan salah pada masalah geometri kemudian memilih subjek yang bergender laki-laki dan perempuan masing-masing 1 orang.

Teknik pengumpulan data pada penelitian ini adalah memberikan TPMG dan wawancara. Setelah subjek penelitian menyelesaikan TPMG maka peneliti melakukan mengkoreksi hasil pekerjaan subjek. Kemudian peneliti memilih 2 subjek yang terdiri dari 1 bergender lakilaki dan 1 bergender perempuan. Setelah terpilih kemudian peneliti melakukan wawancara terhadap 2 subjek tersebut secara mendalam guna memverifikasi data hasil tes tertulis. Selain itu, wawancara juga digunakan untuk memperoleh informasi baru yang mungkin tidak diperoleh saat tugas tertulis, karena tidak semua yang dipikirkan siswa mampu dituliskan, hal ini mungkin dapat terungkap ketika wawancara.

Tahapan analisis data dalam penelitian ini terdiri dari dua, yaitu analisis data kuantitatif dan kualitiatif.

1) Analisis Kuantitatif

Analisis ini digunakan untuk mengetahui secara kuantitatif subjek yang menjawab benar masalah geometri yang diberikan dan bagaimana perbedaan secara kuantitatif berdasarkan gender.

2) Analisis Kualitatif

a) Tahap klasifikasi/kategorisasi data

Data hasil wawancara yang diperoleh selanjutnya dipaparkan, setelah data dipaparkan kemudian menentukan kategori data penalaran spasial yang muncul.

b) Tahap reduksi data

Bertujuan untuk memfokuskan dan menajamkan kategori data penalaran spasial yang telah ditentukan. Menguji keabsahan kategori data penalaran spasial yang diperoleh dengan cara membandingkan kategori data penalaran spasial pada TPMG 1 dan TPMG 2. Data penalaran spasial dikatakan valid jika terdapat konsistensi antara kategori data penalaran pada TPMG 1 dan TPMG 2.

c) Tahap penyajian data

Data penalaran yang valid kemudian disajikan dalam bentuk teks yang bersifat naratif. 
d) Tahap interpretasi/penafsiran data Interpretasi data adalah kegiatan menafsirkan/menerjemahkan data penalaran spasial yang telah diperoleh pada langkah sebelumnya, sebagai dasar untuk menarik kesimpulan.

e) Tahap penarikan kesimpulan

Hasil interpretasi/penafsiran data inilah yang menjadi dasar sebagai penarikan kesimpulan. Penarikan kesimpulan pada penelitian ini ditujukan untuk mendeskripsikan penalaran spasial siswa dalam memecahkan masalah geometri.

\section{HASIL PENELITIAN DAN PEMBA-}

\section{HASAN}

\section{A. Hasil Penelitian}

\section{Data Kuantitatif}

Pengumpulan data kuantitatif dilakukan kepada 124 siswa yang berusia antara 12 tahun hingga 14 tahun yang terdiri dari 61 bergender laki-laki dan 63 siswa bergender perempuan. Hasil pengumpulan data terhadap 124 siswa disajikan pada tabel berikut ini. diketahui adalah sebuah kubus yang memiliki warna yang berbeda disetiap sisinya. Alas kubus berwarna merah, sisi yang berhadapan dengan sisi alas berwarna hitam. Sisi berwarna hijau berada diantara sisi berwarna merah dan hitam. Sisi berwarna biru bersebelahan dengan sisi warna putih dan coklat. Dan menyebutkan yang ditanyakan adalah menggambar jaring-jaring kubus beserta warnanya, menentukan warna sisi yang berhadapan dengan sisi berwarna coklat, menentukan siswa yang berhadapan dengan sisi berwarna biru.

Tahap menyusun rencana, dalam menyusun rencana, yaitu LK menggambar jaring-jaring kubus beserta letak warnanya, dengan cara membayangkan tanpa membuat bendanya.

Tahap menyusun melaksanakan, dalam soal no 1 subjek menggambar jaringjaring kubus dan menentukan sisi alas berwarna merah dengan membayangkan menjadi kubus. Setelah dapat membayangkan kemudian menentukan warna disetiap sisinya. Membayangkan menjadi kubus dan mengungkapkan pasti akan memiliki penutup yang berlawanan dengan

Tabel 1. Jumlah siswa menjawab berdasarkan gender

\begin{tabular}{|c|c|c|c|c|}
\hline \multirow{2}{*}{ Soal } & \multicolumn{4}{|c|}{ Gender } \\
\cline { 2 - 5 } & \multicolumn{2}{|c|}{ Laki-laki } & \multicolumn{2}{c|}{ Perempuan } \\
\cline { 2 - 5 } & Benar & Salah & Benar & Salah \\
\hline 1 & 45 & 16 & 47 & 16 \\
\hline 2 & 41 & 20 & 46 & 17 \\
\hline 3 & 37 & 24 & 36 & 27 \\
\hline
\end{tabular}

\section{Data Kualitatif}

a. Subjek Lak-laki.

Pada tahap memahami masalah, subjek mengumpulkan bukti/data pada masalah dengan LK menyebutkan yang sisi berwarna merah yaitu sisi yang berwarna hitam. Menentukan sisi berwarna hijau, biru, putih, dan coklat dengan membayangkan jaring-jaring menjadi kubus. Soal no 2 adalah membayangkan 
jaring-jaring kubus menjadi kubus sehingga dapat menentukan sisi berwarna hitam dan akan diperoleh sisi yang berhadapan dengan sisi berwarna hitam. LK juga mengungkapkan bahwa tidak perlu menggunakan model kubus untuk mem-bantu menentukan warna yang berhadapan dengan sisi berhasapan dengan sisi berwarnan coklat hanya dengan mem-bayangkan saja. Dan pada soal no 3, subjek membayangkan jaring-jaring menjadi kubus kembali, dan menggulingkan ke depan kubus tersebut agar sisi berwarna hitam menjadi berada di depan yang menye-babkan sisi berwarna biru berada dibagian atas sehingga tinggal membalik lagi dan akan didapatkan sisi yang berhadapan dengan sisi biru.

Tahap memeriksa kembali, subjek membayangkan kembali jaring-jaring kubus menjadi kubus dan memeriksa semua langakah yang dilakukan untuk menjawab soal.

b. Subjek Perempuan.

Pada tahap memahami masalah, Subjek, menyebutkan yang diketahui adalah sebuah kubus, dengan sisi yang memiliki beda warna ada hitam, coklat, hijau, putih merah dan biru, setelah itu sisi warna merah ada dibawah, diatas kubus, sisi warna merah berhadapan dengan sisi warna hitam, pada sisi hijau yang ada diantara merah dan hitam, warna biru bersebelahan dengan warna putih, dan juga ada warna coklat yang bersebelahan dengan sisi warna biru. Dan menyebutkan yang ditanyakan yaitu gambarkan jaring-jaring kubus tersebut beserta warnanya, mentukan warna sisi yang berhadapan dengan sisi berwarna coklat sama nomor 3 jika sisi yang berwarna hitam berada dibagian depan yang bersebelahan dengan sisi yang berwarna biru, dan menentukan warna sisi yang berhadapan dalam sisi yang berwarna biru.

Tahap menyusun rencana, subjek akan menggambar kubus dan kemudian menentukan letak warnanya pada kubus dengan membayangkan.

Tahap menyusun melaksanakan, dalam soal no 1, subjek menggambar kubus, menentukan sisi alas berwarna merah. Setelah dapat menentukan sisi alas kemudian subjek dapat menentukan warna pada sisi yang lain berdasarkan informasi yang diperoleh. Setelah sisi kubus telah ditentukan warnanya subjek kemudian membuat jaring-jaring kubus berdasarkan kubus yang telah dibuat beserta warnanya. Soal no 2, subjek membayangkan jaringjaring kubus menjadi kubus seperti gambar kubus yang telah dibuat sebelumnya sehingga dapat menentukan sisi yang berhadapan dengan sisi berwarna coklat dan diperoleh warna putih. Soal no 3, subjek menentukan sisi yang berhadapan dengan sisi warna biru dengan menggunakan bantuan alat yaitu penghapus yang terlebih dahulu ditentukan dulu warna sisi-sisinya kemudian melaksanakan instruksi sesuai dengan informasi yang diberikan.

Tahap memeriksa kembali, subjek memeriksa kembali jawaban no 1 mengenai letak warna pada jaring-jaring, dan memeriksa kembali jawaban no 3 dengan menggunakan penghapus untuk membantu membayangkan.

\section{B. Pembahasan}

Pada memecahkan masalah geometri yang diberikan, subjek laki-laki memecahkan masalah dengan membayangkan objek tersebut, memanipulasi dan merotasi hanya dalam pikiran tanpa menggunakan bantuan. Ini sejalan yang diungkapkan 
Piaget (dalam Simatwa, 2010), bahwa tahapan operasional formal siswa sudah tidak menggunakan benda/objek konkret untuk membantu ber-pikir.

Subjek perempuan memecahkan soal no 3 , dengan menentukan sisi yang berhadapan dengan sisi warna biru dengan menggunakan bantuan alat yaitu penghapus yang terlebih dahulu ditentukan dulu warna sisi-sisinya kemudian melaksanakan instruksi sesuai dengan informasi yang diberikan. Ini terlihat penalaran spasial subjek masih pada tahap operasional konkret, anak mulai mengembangkan pemikiran spasial dari suatu gambar tetapi msih membutuhkan tampilan aktual dari objek yang dimanupulasinya (dalam Simatwa, 2010).

\section{KESIMPULAN}

1. Sebanyak 45 siswa gender laki-laki yang menjawab dengan benar soal no 1, 41 siswa gender laki-laki yang menjawab dengan benar soal no 2 , dan 37 siswa gender laki-laki yang menjawab dengan benar soal no 3 . Dalam memecahkan masalah geometri subjek gender laki-laki membayangkan jaring-jaring menjadi sebuah kubus.

2. Sebanyak 47 siswa gender perempuan yang menjawab dengan benar soal no 1, 46 siswa gender perempuan yang menjawab dengan benar soal no 2 , dan 36 siswa gender perempuan yang menjawab dengan benar soal no 3 . Dalam memecahkan masalah geometri subjek gender perempuan membuat jaring-jaring dari kertas membayangkan jaring-jaring menjadi sebuah kubus dan menggunakan alat bantu (penghapus).

\section{DAFTAR PUSTAKA}

Mullis, I.V.S., Martin M.O., Foy, P., Arora, A. (2012). TIMSS 2011 International Result in Mathematics. Chestnut Hill, MA: TIMSS \& PIRLS International Study Center. Boston College.

Risalah, D., et. al. (2016). Case Study Spatial Reasoning in Student Junior High School Solve Problems Geometry. IQSR Journal of Mathematics, Vol 12 Issue 6. pISSN 2319$765 X$.

Simatwa, E. M. W. (2010). Piaget's Theory on Intellectual Development and Its Implication for Instructional Management at Pre-secondary School Level. Educational Resea-rch and Review, Vol 5. ISSN 1990-3839.

Stacey, K.. (2010). Mathematics Teaching And Learning To Reach Beyond The Basics. Research Conference: University of Melbourne.

Subarinah, S. (2013). Profil Berpikir Kreatif Siswa Dalam Memecahkan Masalah Tipe Investigasi Matematik Ditinjau Dari Perbedaan Gender. Makalah PROSIDING Seminar Nasional Matematika dan Pendidikan Matematika.FMIPA UNY ISBN : 978 $-979-16353-9-4$. 